\title{
Extending the flipped classroom model: Developing second language writing skills through student-created digital videos
}

\begin{abstract}
Marion Engin ${ }^{1}$
Abstract: This paper describes a project that aimed to leverage the students' interest and experience of technology and multimodal environments to develop their academic writing skills and second language learning. Students were expected to follow a model, research a topic, and craft a digital video tutorial on an aspect of academic writing which would form part of the already established flipped classroom model. Feedback from students suggests that there was tension between students as producers, and students as consumers. Student-created videos promoted second language learning through research, simplification, explanation, and encouraged more focus on form, promoting accuracy in English. However, it was also noted that students prefer a teacher explanation than a peer explanation and there were concerns over the "trustworthiness" of a peerproduced video tutorial.
\end{abstract}

Keywords: flipped classroom, digital videos, peer teaching, meaningful learning, technology

\section{Introduction}

Technology has become a significant part of university life (Goode, 2010), and students are immersed in a multimodal environment both inside and outside the classroom. The challenge facing educators in higher education is how to leverage the students' interest and experience of technology in fulfilling the learning outcomes of a course. In a second language-learning context, this means incorporating technology to develop the learners' writing skills in terms of linguistic accuracy and fluency, organization, and lexical appropriacy.

Kirkwood and Price (2013) call for a scholarly approach to examining the impact of technology on learning. Drawing on a review of the literature, they conclude that instructors tend to choose a technology and teacher-led approach, rather than a learning and learner-led approach. Thus a scholarly approach to exploring the impact of technology on learning would involve inquiry and evidence, as well as reflection of one's own teaching practice and learning within one's own context. This paper is an attempt to examine the impact of student-created digital videos on second language learning in an academic writing course through a scholarly approach, with particular focus on inquiry, evidence, and reflection Evidence of learning was found in the responses of students to the questionnaires and interviews, as well as in the final product of the videos. Student reflections on the process are also shared in this paper, highlighting some fundamental considerations in the flipped classroom model and peer teaching.

\footnotetext{
${ }^{1}$ Zayed University, United Arab Emirates
} 


\section{Background}

In the United Arab Emirates, mobile learning has entered the educational landscape with such force and impact that it is no longer possible to ignore the push to incorporate mobile technology into the classroom (Cavanaugh, Hargis, Munns, \& Kamali, 2012; Gitsaki, Robby, Priest, Hamdan, \& Ben-Chabane, 2013). However, although technology can enable learning, it does not necessarily ensure learning (Kirkwood \& Price, 2005). In the university in which this study is set, students and teachers were expected to incorporate technology into the learning outcomes of the courses. A second language-writing course was no exception. One way it was felt that technology could play an important role in learning was through a flipped classroom approach. A flipped classroom means that students are exposed to new content outside of the class through short videos, and then use the class time to further develop this knowledge through problem-solving, discussion, practice, and interaction with peers and teacher (Brame, 2013).

This study builds on an earlier research the author co-conducted into flipping the classroom in a second language academic writing course (Engin \& Donanci, 2014). In that study, the authors devised a flipped classroom model as part of the course. Findings suggested that the flipped model gave students the opportunity to learn in their own time at their own pace, as well as give them a repository of video tutorials to be used for review purposes. However, the study did not explore to what extent the students developed their language skills. Furthermore, despite the positive response to the flipped model, it was felt by the author that students were passive consumers rather than active producers (Beach, 2012). It was felt that the students could be further engaged in their learning (Herreid \& Schiller, 2013; Nielsen, 2012), and could be more active in developing their language skills. Having considered the literature on student-created digital videos (Greene \& Crespi, 2012; Holtzblatt \& Tschakert, 2011), it was felt that peer teaching through a variety of technological devices and applications would make the students more active in their learning, would demand more linguistic output, and would give students responsibility for researching part of the content of the course. In other words, they would become producers as well as consumers.

This study describes the various steps of the project, student activities, and examines the impact of the project on students' language and academic writing skills. The author prepared a bank of short videos on aspects of academic writing as possible models, and then the students were tasked with creating their own digital video on an aspect of academic writing agreed with the teacher. The students in this study were native Arabic speakers, thus English was their second language. As a result, the aim of promoting student-generated material and input through videos was to lower the cognitive, linguistic, and cultural loads which could act as a barrier to meaningful learning (Meyer, 2000). A fundamental premise of using the flipped classroom model, and involving students in creating video tutorials is that by talking about a topic, or explaining a topic, and guiding another learner, learning can take place (Mercer, 1995, 2000). The aim of the research was to explore the extent to which student-created digital videos could develop language and writing skills in a second language. The next section situates the project in a pedagogical framework of peer instruction and flipped learning.

\section{Peer teaching}

Peer teaching gives students the responsibility for scaffolding their classmates' learning. Scaffolding as a metaphor to describe the assistance a teacher or more knowledgeable peer can 
give in a learning context derived from the work of Wood, Bruner and Ross (1976). Scaffolding was introduced in the context of tutorials and refers to the help given by a teacher or more able peer in an educational setting. Although this support is often the teacher, there is agreement that a more able peer can fulfill the same role (Maybin, Mercer, \& Stierer, 1992). Thus the opportunity for peer teaching enables learners to take on the role of expert, or more able peer (Goldschmid \& Goldschmid, 1976).

This study aimed to promote peer and reciprocal teaching through video tutorials. Reciprocal teaching aims to break the typical pattern of skill training where the student is a passive participant responding, rather than initiating or acting. In reciprocal teaching, the student starts as a novice, and with guidance and modeling, takes on a role of expert in a supported context (Palincsar \& Brown, 1984). The movement from novice to expert requires appropriate activities, guidance, and intervention (Shuell, 1990).

Benefits of peer teaching include deeper understanding of course content, increased critical thinking, willingness to explore, and self-reflection (Yang \& Wu, 2012; Velez, Cano, Whittington, \& Wolf, 2011). A significant benefit of peer teaching is that the "teacher" student learns the content better themselves "Students who tutor other students profit not only on a cognitive level (i.e., become more expert in the subject they are teaching), but also on an interpersonal, affective one." There is also evidence that students retain more when they teach a topic (Velez et al., 2011).

In this project the learner was required to articulate his or her own understanding of an aspect of academic writing through the video tutorial. Talking about the topic fixes the idea and concept deeper in the mind (Durkehim, 1956, cited by Lauder et al., 2006). Furthermore, the students were learning English as a second language, thus the task of summarizing and explaining gave considerable language practice in terms of both fluency and accuracy. In other words, the articulation of understanding, and the explanations of the topic, support the learner's own comprehension of the topic as well as support his or her second language development. Very simply, by teaching the topic, the learner learns (Velez et al., 2011).

\section{The flipped classroom and second language learning}

A flipped classroom is part of a blended learning model in which students have some control over 'time, place, path and/or pace' (Staker \& Horn, 2012) and are involved in active learning (Hamdan, Mcknight, Mcknight, \& Arfstrom, 2013). A flipped approach is not just a pedagogic model, it is a mindset as to what the teacher and students' roles are, and how best to support student learning (Bergmann \& Sams, 2012). The flipped model means that the input is given out of the class through digital video tutorials, and what was formerly done at home is now carried out in class. Thus, in class teachers can work with students in a one-on-one tutorial mode (Hamdan et al., 2013). Flipping the classroom builds on the already existing mobile technological tools which students use outside the classroom and reinforces the idea that learning does not have to take place only in 'brick-and-mortar location' establishments (Staker \& Horn, 2012).

A flipped classroom approach has been used successfully in K-12 contexts in science (Bergman \& Sams, 2012), math (Fulton, 2013; Johnson, 2007), in Language Arts (Fulton, 2013; Ullman, 2013) and in higher education contexts with pharmaceutical students (Ryan, 2013), statistics courses (Strayer, 2007), and cinema and TV arts students (Enfield, 2013). Reports on flipped classrooms tend to come out of research in science, technology, engineering, and math 
(STEM) subjects (Berrett, 2012). The Economist also notes that Khan Academy videos tend to be for the "numerate" subjects ("Hopes that the internet can improve teaching may at last be bearing fruit," 2011). However, there have been almost no reports of the flipped classroom model in second language learning. Kukulska-Hulme and Shield (2008) report on how mobile learning is impacting on opportunities and different interactions in second language learning, but do not highlight studies using the flipped classroom model. This may be due to the fact that second language lessons cannot be "packaged" into a short video tutorial.

\section{Student-created digital videos and second language learning}

Despite the benefits reported on student learning, in a flipped classroom it is still the teacher who lectures and gives the input (Nielsen, 2012), and the students who "sit-and-get" ('Hopes that the internet can improve teaching may at last be bearing fruit,' 2011). The aim of this project to involve students in the production as well as the consumption of the digital videos (Beach, 2012) encouraging them to move from novice to expert in the area of academic writing skills (Shuell, 1990). Through the activity of student created video input learners move from novice to expert by researching, comprehending, evaluating, and creating. It is noteworthy that these stages also closely correspond to Bloom's taxonomy (Holtzblatt \& Tschakert, 2011) and the taxonomy suggested by Krathwohl (2002) which includes the highest level of cognitive processing - create. The creation of the video involves not only greater comprehension, but also higher levels of cognitive processing in order to be able to explain a topic to peers (Rodriguez, Frey, Dawson, Lieu, \& Rotzhaupt, 2012).

Reports of student-created digital videos in the K-12 context are numerous. Kearney and Schuck (2006) survey nine school projects where students created videos for other students on topics such as French, Science, and Language Arts. Benefits in terms of content include greater relevance, more meaningful input, and greater awareness of peers and audience. Similarly, Yang and $\mathrm{Wu}$ (2012) asked school students to create digital stories which they found increased students' understanding of course content and developed critical thinking skills. Beach (2012) outlines how student-created videos developed students' sense of effective visual communication as a result of audience awareness.

In the higher education context, there are reports on projects using student-created digital videos in courses on physical education (Lim, Pellett, \& Pellett, 2009), computing, accounting, and early childhood studies (Schenborn, Poverjuc, Campbell-Barr, \& Dalton, 2013), marketing and accounting (Greene \& Crespi, 2012), and accounting (Hotzblatt \& Tschakert, 2011). The authors report many positive results such as increased motivation and increased reinforcement of concepts. Student-created videos have also been used in teacher education contexts (Miller, 2007).

However, there is a paucity of research and literature into the impact of a flipped classroom and student-created videos in a second language-learning context. Kukulska-Hulme and Shield (2008) give an overview of mobile learning and language learning, but the focus was more on the opportunities for communication practice outside the classroom. Kukulska-Hulme (2009) discusses how mobile learning can change the way in which languages are learned, and makes reference to how students may be involved in the creation of material. However, there is little research that specifically examines the impact of student-created videos on language learning and writing skills in a context where students become the producers as well as the consumers. 
Engin, M.

\section{Research questions}

The research questions were:

- How did students creating digital videos on aspects of academic writing develop their language and writing skills in English?

- How did students feel about learning from student-created videos?

\section{Method}

\section{Context}

This study was set in a federal university in the United Arab Emirates. Students are required to take three composition classes before they start their major. The course in this study was the third composition class. The author used a flipped classroom model so that students watched some of the lesson input in short tutorial videos at home, and then spent precious class time working on research and writing, with the author able to give one-on-one support, guidance and feedback (documented in Engin \& Donanci, 2014). In previous classes, the author had prepared a range of video tutorials. However, it became clear that although students were watching them, they were not interacting with the content of the video, nor engaging as active learners. The author decided to involve the students in creating a library of digital video tutorials for the class.

\section{Participants}

The class was a group of 18 Emirati female learners aged 19-21 who were taking their third and final composition class before they started major requirements. Their first language is Arabic, with English being their second language. All participants gave informed consent. Permission to conduct research was granted by the Research Ethics Committee of the university.

\section{Procedure}

The author prepared ten digital videos on a variety of topics at the beginning of the semester. Topics included writing a research question, organizing an argumentative essay, outlining, and writing a research proposal. These were placed in a Learning Management System (Blackboard), a repository accessible to students from any platform with wireless connection. These videos were designed as scaffolds (Pan, Sen, Starett, Bonk, Rodgers, Tikoo, \& Powell, 2012) to give students a possible model, and to orient them to the concept of video tutorials and how to use them. The author prepared a list of topics which she felt would lend themselves to "how to" tutorials. The main outcome of the academic writing course was a 2,000 argumentative researched paper on a topic that was negotiated between student and instructor. The secondary outcomes of the course were specific language and writing skills to support their final paper, as well as information literacy skills. These skills were listed for the students to choose from. The skills included paraphrasing, summarizing, writing a thesis statement, using in-text citations (APA) and writing a reference list (APA). Students in pairs chose on which topic they wanted to prepare a video. Students prepared the videos according to a schedule, and sent them to the 
teacher to be checked. The teacher then placed them either in Blackboard as a video file, or a link (URL), or Webdav.

\section{Instruments}

A two-part questionnaire was distributed (see Appendix A). The first part was designed to get feedback on the flipped approach and the use of the videos, thus the students were surveyed on their perceptions of the digital videos in their roles of consumers. The second part aimed to elicit perceptions of the usefulness of creating their digital video and the extent to which the creation and preparation enhanced their own knowledge and understanding of the concepts, as well as their language. The questionnaire was developed from the questionnaire described in Engin and Donanci (2014). The new questionnaire was checked by the Research Ethics Committee of the university. Following the questionnaire, the author conducted informal and unstructured interviews with five students to follow up on issues highlighted in the responses to the questionnaire. These five students volunteered to be interviewed. The author recorded the interviews on a mobile phone, and took notes during the interviews. All data was confidential and anonymous.

The data were analyzed for themes related to content and language, and what helped the learning. Although the questions in the questionnaire did not directly prompt students to think about their language learning, it was implicit in all the questions.

\section{Results}

The first research question focused on how the creation of a digital video on an aspect of academic writing helped students to develop their own writing skills and their language skills. From the responses, several themes emerged which related to the process of creation, and the link to language learning. These were the processes of researching and evaluating the information, and the focus on language form and accuracy in preparing and explaining

\section{Language skills development through researching}

Many students mentioned that the act of researching a topic, searching for sources, evaluating the information and choosing relevant information helped them to learn the topic better. The research they do for the video is focused and meaningful as students are required to make connections with what they know and what they need to know (Perlman, Weston, \& Gisel 2010). The activity of finding information, evaluating it, and then summarizing is part of Bloom's taxonomy and encourages higher order thinking skills (Krathwohl, 2002). Many students were able to articulate very clearly the stages they went through in creating the video. They all researched and focused on content before they thought about the media to use for the digital video. I was concerned that the excitement of using media technology and applications to prepare the tutorial would detract from the content aspect, but all students started with the stages of content research and evaluation, and only when they were satisfied with the content did they start thinking of how they could be creative. One student commented, "[The process was] first searching, reading, choosing best points, organize, using creative mind to make the video." Another student mentioned how doing the research about the topic gave her a better 
understanding of the topic, "[I understand the topic better] because I did research about it and that gave a clear picture about the topic."

Some students explained how they had to select the relevant information for their tutorial. The process of gathering information, selecting, and evaluating is akin to the process Shuell (1990) describes when he discusses the transition from novice to expert. In this project, students were expected to be independent learners by finding their own information and the evaluating it with regard to their purpose. One student wrote, "When I searched I found things I didn't know." This statement suggests that the student was becoming more like an expert in their chosen topic. In fact, in the interviews one student mentioned how she was now considered an expert in the area of writing thesis statements. The student had used her knowledge of writing thesis statements for an essay in her Global Studies class, with very positive feedback. Moreover, a student in the Global Studies class had asked for her help in writing a thesis statement. These comments indicate that the student had moved from a position of novice to expert on an aspect of academic writing through her own research and development of knowledge.

\section{Language development through simplifying}

Many students mentioned the activity of simplifying the information as part of the process. Simplifying the material is a higher order cognitive skill as it involves summarizing and synthesizing, as well as paraphrasing. Understanding is crucial to being able to simplify. It was felt by the students that presenting the material as they found it would not be appropriate. The process of simplifying it for their classmates was significant as students had to first understand the topic themselves. Students talked about the fact that being at the same level as their classmates made it easier for them to know how much to simplify the material. The act of simplifying helped them to learn the topic better. One student commented, "I have to learn it to make it easier for the girls." Simplifying content in a second language also involves comprehension, manipulating language, selection of appropriate vocabulary, and a focus on form. This activity therefore gave opportunities for English language practice.

Having to research and choose relevant information forces students out of their comfort zone and gives them responsibility for their own learning (Ryan, 2013). It was a concern of mine that they would spend more time on the creative and technical aspect of the project, but in all description of the process, more attention was paid to the research and collecting content elements of the project. They also mentioned that they did not start preparing the video until they understood the topic themselves. One student wrote, "When we understand, then we make the video."

\section{Language development through a focus on accuracy}

Preparation of the content with the audience in mind seemed to support language learning through a focus on accuracy of content and language. Audience awareness forced students to be careful in choosing content and appropriate language for explanations. Kearney and Schuck (2006) describe audience awareness as a positive benefit, but do not explain the particular reasons why audience awareness is important. In this study, it seemed the fear of giving the wrong information was key in guiding the content and the explanations. Students mentioned how they were afraid of giving wrong information and making mistakes. As a result, they had to be very sure of what they were teaching, and check their work several times. A focus on accuracy of

Journal of the Scholarship of Teaching and Learning, Vol. 14, No. 5, December 2014. 
information and content further develops their own knowledge of the subject. Repetition of the content can strengthen an understanding of concepts. One student wrote, "I had to absorb the topic in order to deliver the right meaning." This suggests that students made sure they fully understood the topic before they felt ready to prepare their tutorial.

Since students had to monitor their language as they would be recording the lesson and sharing it with others, this new consumer awareness prompted students to focus on their accuracy in English. Several students mentioned the fear of making mistakes. In the interviews, when asked how the knowledge that peers would watch the video affected their choice of content and language, one response was "We have to do it perfect because it's for learning and to gain information. We had to think it must be the right way so have to do it serious." Interestingly, this worry was seen as a positive influence on their language. "It was a good thing to worry about our English because we improve our English." The course the students were taking was an academic writing course that required both accurate and appropriate use of English. Thus, the pressure to produce accurate English is a positive benefit of making the video public to classmates.

\section{Student perceptions: trustworthiness of the content and presentation}

The second research question focused on the perceptions of students and how useful they found the creation of digital videos for their classmates. One theme that emerged strongly throughout the data was the lack of trustworthiness in classmates' knowledge.

Although there were positive comments about working in groups and cooperating on a joint project in terms of the production, many students commented on the quality of the videos in terms of their roles as consumers. In both the interviews and questionnaires, comments were made which pointed to a lack of confidence in non-teacher prepared material. This was from both a content and presentation point of view. Although the teacher prepared the first few videos as possible models, students were not always confident of the content of their classmates' videos. One student commented, "Students' videos are good but might contain some wrong information."

Students were also concerned about the presentation style of their classmates, and commented on the fact that they were used to the teacher's presentation style. They felt that classmates might not explain clearly, and that their presentation style might not help them. One student wrote, "I trust the teacher's way in the video." Another commented on the explanations: "The teacher always explains better, students might not explain clearly." Trust and confidence in both the content and the presentation style is clearly a crucial factor in the students' perception of the effectiveness of watching the videos as a form of input.

\section{Discussion}

\section{Second language learning through student-created digital videos}

This study aimed to evaluate the impact of student-created digital video tutorials on language learning in an academic writing course. This study builds on previous research carried out into the flipped model and digital videos in academic writing programs (Engin \& Donanci, 2014), and develops our knowledge base of how student-created digital videos can promote collaboration and meaningful learning through peer-teaching in a media-rich technological environment. The approach taken for this study is scholarly in that it highlights previous work, 
builds on research, and examined a specific technological teaching strategy in a systematic and rigorous way (Kirkwood \& Price, 2013). Previous research indicates that there are significant motivational and attitudinal benefits for students as consumers when the input is 'teacher-made' (Engin \& Donanci, 2014). However, the current research indicates that second language learning opportunities arise when students take on the role of producer.

In terms of learning about writing, it would seem that the process of researching, collecting, and explaining information on an area of academic writing is a key stage in the development of knowledge. Students were independent learners having to research and evaluate resources that they could use for their tutorial. The evaluation of resources is a crucial part of information literacy (Thompson, Morton, \& Storch, 2013), and a key learning outcome of their composition course. Similarly, explaining processes and giving rationales were found to place high cognitive demand on learners (Rodriguez et al., 2012). Learning content was also supported by the activity of peer teaching. Similar to benefits identified by Velez et al. (2011), students enjoyed the collaborative aspect of peer teaching. However, unlike Velez et al.'s (2011) evaluation, the most beneficial aspect of the peer teaching approach was that the student "teacher" learned from teaching the topic (Topping, 2005). Although scaffolding generally examines learning and development from the perspective of the less able peer, in this case it would seem that the "expert" or more able peer reaped most rewards in the role of producer.

In terms of developing language skills, the activity of simplification required comprehension, paraphrasing and manipulation of language. The articulation of this information through verbal explanations further developed language skills. Focus on form and accuracy in the explanations stemmed from a new awareness of the consumer and public viewing. "Students' awareness of their peers as the target audience was an incentive for them to understand curriculum materials and related concepts and to carefully select and use appropriate language in their films" (Kearney \& Schuck, 2006, p. 187). While this is a noteworthy outcome in a Language Arts program, it is of particular significance in a second language classroom. The shift from awareness of self as author, to peers as audience, creates a pressure to be accurate and monitor language.

While the benefits of creating a video tutorial in the role of producer are highlighted above, the benefits for the consumers of student-created videos are less positive. This may stem from the concerns that students raised as to the "trustworthiness" of both the content and the teaching style of the student-created videos. There are two issues in this discussion. Firstly, students were concerned as to the accuracy of the content. Secondly, and more fundamentally, students required follow-up teacher explanations in class regardless of who made the video tutorial. This results from the flipped model rather than the student-created videos. Arnold-Gaza (2014) found that students were not ready to relinquish classroom time for explanations and be completely independent in library studies. Similarly, Herreid and Schiller (2013) suggest that students may be resistant at first to a flipped approach, as they have to do more work at home. Much of the research on student-created videos highlight the benefits of students as creators, but do not examine students' attitudes as consumers to peer-produced videos (Beach, 2012; Kearney \& Schuck, 2006).

\section{Limitations of the study}

Kirkwood and Price (2013) call for the need to examine the impact of technology on student learning with rigorous procedures and evidence. In a study such as this one, evidence 
may be found in a variety of areas. This study explored perceptions of their language learning as evidence. One limitation therefore of this study is that the videos themselves were not critically analyzed for evidence of understanding of the topic. Rodriguez et al. (2012) point out that the digital artifacts need to be evaluated for their content, purpose, cognitive demand, technology, and ethical use. Only then can learning be evaluated in terms of whether the students were using higher level cognitive processing. This is certainly an area to focus on in future studies.

Secondly, the participant group was a small sample size (Chester, 2012). The results therefore should be read in the light of this particular group. This research could be viewed as a case study, in a very particular educational, linguistic, and cultural context. However, the second language academic writing environment is common to many contexts and it is hoped that some of the learning points will resonate with teachers working in similar contexts.

\section{Lessons learnt and future projects}

This study contributes to research on flipped classrooms and builds on work on pedagogical models of second language learning. To date, there has been little examination of how student-created videos can contribute to language learning in a flipped model classroom. This paper is an attempt to merge the study of flipped classroom pedagogy with student-created videos. As can be seen, students developed their language fluency and accuracy through the project. However, students were clear that they still want teacher explanations in class. Further work with students on preparing digital videos will include more orientation to the flipped model and peer teaching in terms of students' roles and responsibilities (Schoenborn et al., 2013). As Kirkwood and Price (2005) point out, it is crucial that students know the purpose of working with technology. In their reflections students mentioned that they needed more support on how to structure their video tutorial, displaying the need for more careful task preparation around the project (Herreid \& Schiller, 2013). It is also important to ensure that the purposes of the digital videos are congruent with the aims and outcomes of the writing course (Hofer \& Owings Swan, 2005). What has become clear from the literature is that to date, research has either explored the effectiveness of the flipped classroom model, or the impact of student-created videos on motivation, collaboration, and learning. However, research on the role of students in the flipped classroom needs to focus on students as both consumers and producers of digital material. What is needed is a framework that merges the two. When students create material for a particular audience in a flipped classroom, it is significant to study the impact and effectiveness of peerprepared material on learning. Only then can we evaluate the learning potential of studentcreated digital videos.

\section{Appendix}

\section{PART A: Watching and learning}

1. Did you watch the videos the teacher sent you?

2. How often did you watch them?

3. Did you watch the videos your classmates prepared?

4. How often?

5. Did you find them useful? Why?

6. What did you find useful in the videos? 
Engin, M.

7. Did you find the videos help you understand the topic? If yes, why?

\section{PART B: Preparing the video}

1. What process did you go through when preparing the teaching video?

2. Did you enjoy preparing the teaching video? If yes, why? If no, why not?

3. Did you learn anything from preparing the video? If yes, what?

4. What suggestions can you give your teacher about this project?

\section{References}

Arnold-Gaza, S. (2014). The flipped classroom: Assessing an innovative teaching model for effective and engaging library instruction. College and Research Libraries News, 75 (1), 10-13. Retrieved from: https://myzu.zu.ac.ae/ehost/pdfviewer/,DanaInfo $=$.awfdCfEki0lys057Os54+pdfviewer?sid=0d15 57df-9683-4f63-8eb8-dcd0325770ca\%40sessionmgr110\&vid=5\&hid=103

Beach, R. (2012). Uses of digital tools and literacies in the English language arts classroom. Research in the Schools, 19 (1), 45-59.

Bergmann, J., \& Sams, A. (2012). Flip your classroom: Reach every student in every class every day. International Society for Technology in Education.

Berrett, D. (2012, February 19). How 'flipping' the classroom can improve the traditional lecture. The Chronicle of Higher Education. Retrieved from: http://chronicle.com/article/HowFlipping-the-Classroom/130857/

Brame, C. J. (2013). Flipping the classroom. Retrieved from: http://cft.vanderbilt.edu/guidessub-pages/flipping-the-classroom/

Cavanaugh, C., Hargis, J., Munns, S. \& Kamali, T. (2012). iCelebrate teaching and learning: Sharing the iPad experience. Journal of Teaching and Learning with Technology, 1 (2), 1-12.

Chester, A. (2012). Peer partnerships in teaching: Evaluation of a voluntary model of professional development in tertiary education. Journal of the Scholarship of Teaching and Learning, 12 (2), 94-108.

Doering, A., Beach, R., \& O’Brien, D. (2007). Infusing multimodal tools and digital literacies into an English education program. English Education, 41-60.

Durkheim, E. (2006). Education: Its nature and its role. In H. Lauder, P. Brown, J. Dillabough, \& A. A. Halsey (Eds.). Education, globalisation, and social change. Oxford: Oxford University Press. 
Engin, M.

Enfield, J. (2013). Looking at the impact of the flipped classroom model of instruction on undergraduate multimedia students at CSUN. TechTrends, 57 (6), 14-27. doi: 10.1007/s11528013-0698-1

Engin, M., \& Donanci, S. (2014). Flipping the classroom in an academic writing course. Journal of Teaching and Learning with Technology, 3 (1), 94-98. doi: 10.14434/jotlt.v3n1.4088

Fulton, K. (2013, March). Byron's flipped classrooms. Retrieved from: http://www.aasa.org/content.aspx?id=27488

Gitsaki, C., Robby, M. A., Priest, T., Hamdan, K., \& Ben-Chabane, T. (2013). A research agenda for the UAE iPad initiative. Learning and Teaching in Higher Education: Gulf Perspectives, 10 (2), 1-15.

Goldschmid, B., \& Goldschmid, M. L. (1976). Peer teaching in higher education: A review. Higher Education, 5 (1), 9-33. doi: 10.1007/BF01677204

Goode, J. (2010). The digital identity divide: How technology knowledge impacts college students. New Media and Society, 12 (3), 497-512. doi: 10.1177/1461444809343560

Greene, H., \& Crespi, C. (2012). The value of student created videos in the college classroom An exploratory study in marketing and accounting. International Journal of Arts \& Sciences, 5 (1), 273-283.

Hamdan, N., Mcknight, P., Mcknight, K., \& Arfstrom, K. (2013). A review of flipped learning. Pearson and George Mason. Retrieved from:

http://www.flippedlearning.org/cms/lib07/VA01923112/Centricity/Domain/41/WhitePaper_Fli ppedLearning.pdf.

Herreid, C. F., \& Schiller, N. (2013). Case studies and the flipped classroom. Journal of College Science Teaching, 42 (5), 62-66.

Hofer, M., \& Owings Swan, K. (2005). Digital moviemaking - The harmonization of technology, pedagogy, and content. International Journal of Technology in Teaching and Learning, 1 (2), 102-110.

Holtzblatt, M., \& Tschakert, N. (2011). Expanding your accounting class with digital video technology. Journal of Accounting Education, 100-121. doi: 10.1016/j.jaccedu.2011.10.003

Hopes that the Internet can improve teaching may at last be bearing fruit. (2011, Sept 17). The Economist. Retrieved from: http://www.economist.com/node/21529062

Johnson, (2013). Student perceptions of the flipped classroom. (Masters of Arts Dissertation). Retrieved from:

https://circle.ubc.ca/bitstream/handle/2429/44070/ubc 2013 spring johnson graham.pdf?seque $\underline{\text { nce }=1}$ 
Kearney, M., \& Schuck, S. (2006). Spotlight on authentic learning: Student developed digital video projects. Australasian Journal of Educational Technology, 22 (2), 189-208.

Kirkwood, A., \& Price, L. (2005). Learners and learning in the twenty-first century: what do we know about students' attitudes towards and experiences of information and communication technologies that will help us design courses? Studies in Higher Education, 30 (3), 257-274. doi: $10.1080 / 03075070500095689$

Kirkwood, A., \& Price, L. (2013). Missing: Evidence of a scholarly approach to teaching and learning with technology in higher education. Teaching in Higher Education, 18 (3), 327-337. doi: 10.1080/13562517.2013.773419

Krathwohl, D. R. (2002). A revision of Bloom's taxonomy: An overview. Theory into Practice, 41 (4), 212-264. doi: 10.1207/s15430421tip4104_2

Kukulska-Hulme, A. (2009). Will mobile learning change language learning? ReCALL, 21 (2), 157-165. doi: 10.1017/S0958344009000202

Kukulska-Hulme, A. \& Shield, L. (2008). An overview of mobile assisted language learning: From content delivery to supported collaboration and interaction. ReCALL, 20 (3), 271-289. doi: $10.1017 / \mathrm{S} 0958344008000335$

Lim, J., Pellett, H. H., \& Pellett, T. (2009). Integrating digital video technology in the classroom. Journal of Physical Education, Recreation \& Dance, 80 (6), 40-55. doi:

10.1080/07303084.2009.10598339

Maybin, J., Mercer, N., \& Stierer, B. 1992. 'Scaffolding' learning in the classroom. In K. Norman (Ed.), Thinking voices: The work of the National Oracy Project. London: Hodder \& Stoughton.

Mercer, N. (1995). The guided construction of knowledge: Talk amongst teachers and learners. Clevedon: Multilingual Matters Ltd.

Mercer, N. (2000). Words and minds: How we use language to think together. London: Routledge. doi: 10.4324/9780203464984

Meyer, L. M. (2000). Barriers to meaningful instruction for English learners. Theory into Practice, 39 (4), 228-236. doi: 10.1207/s15430421tip3904_6

Miller, S. M. (2007). English teacher learning for new times: Digital video composing as multimodal literacy practice. English Education, 40 (1), 61-83.

Nielsen, L. (2012). Five reasons I'm not flipping over the flipped classroom. Technology and Learning, Retrieved from: http://www.techlearning.com/Default.aspx?tabid=67\&EntryId=3379 
Engin, M.

Palincsar, A. S., \& Brown, A.L. (1984). Reciprocal teaching of comprehension - fostering and comprehension-monitoring activities. Cognition and Instruction, 1 (2), 117-175. doi:

10.1207/s1532690xci0102_1

Pan, G., Sen, S., Starrett, D.A., Bonk, C.J., Rodgers, M.L., Tikoo, M., \& Powell, D.V. (2012). Instructor-made videos as a learner scaffolding tool. MERLOT Journal of Online Learning and Teaching, 8 (4), 298-311.

Perlman, C., Weston, C. \& Gisel, E. (2010). Enabling meaningful learning through Web-based instruction with occupational therapy students. Education Technology Research Development, 58 (2), 191-210. doi: 10.1007/s11423-008-9097-2

Rodriguez, P. M., Frey, C., Dawson, K., Liu, F., \& Rotzhaupt, A. D. (2012). Examining student digital artifacts during a year-long technology integration initiative. Computers in the Schools, 29 (4), 355-374. doi: 10.1080/07380569.2012.737293

Ryan, B. (2013). Flipping over: Student-centered learning and assessment. Journal of Perspectives in Applied Academic Practice, 1 (2), 30-39. doi: 10.14297/jpaap.v1i2.64

Schoenborn, P., Pverjuc, O., Campbell-Barr, V., \& Dalton, F. (2013). Challenges of 'students as producers' in web 2.0: A reflective account. Journal of Teaching and Learning with Technology, $2(2), 5-20$.

Shuell, T. J. (1990). Phases of meaningful learning. Review of Educational Research, 60 (4), 531-547. doi: 10.3102/00346543060004531

Staker, H., \& Horn, M. B. (2012, May). Classifying K-12 blended learning. Retrieved from: http://brokersofexpertise.net/cognoti/content/file/resources/documents/13/1319d4c9/1319d4c97 e8faaa11702c08691abc208dcdad43f/downloadedfile_6158012205637240566_Classifying-K12-blended-learning2.pdf.

Strayer, J. F. (2007). The effects of the classroom flip on the learning environment: A comparison of learning activity in a traditional classroom and a flip classroom that used an intelligent tutoring system (Doctoral Dissertation). Retrieved from:

http://faculty.washington.edu/rvanderp/DLData/FlippingClassDis.pdf

Topping, K. J. (2005). Trends in peer learning. Educational Psychology, 25 (6), 631-645. doi: $10.1080 / 01443410500345172$

Thompson, C., Morton, J., \& Storch, N. (2013). Where from, who, why and how? A study of the use of sources by first year L2 university students. Journal of English for Academic Purposes, 12 (2), 99-109. doi: 10.1016/j.jeap.2012.11.004

Ullman, E. (2013). Tips and tools for the flipped classroom. Retrieved from: http://www.techlearning.com/features/0039/tools-and-tips-for-the-flipped-classroom/53725 
Velez, J. J., Cano, J., Whittington, M. S., \& Wolf, K. J. (2011). Cultivating change through peer teaching. Journal of Agricultural Education, 52 (1), 40-49. doi: 10.5032/jae.2011.01040

Wood, D., Bruner, J. S., \& Ross, G. (1976). The role of tutoring and problem solving. Journal of Child Psychology and Psychiatry, 17, 89-100. doi: 10.1111/j.1469-7610.1976.tb00381.x

Yang, Y. C., \& Wu, W. I. (2012). Digital story telling for enhancing student academic achievement, critical thinking, and learning motivation: A year-long experimental study. Computers \& Education, 59 (2), 339-352. doi: 10.1016/j.compedu.2011.12.012 